Pacific Northwest

National Laboratory

Operated by Battelle for the

U.S. Department of Energy

\title{
Testing IH Instrumentation: Analysis of 1996-1998 Tank Ventilation Data in Terms of Characterizing a Transient Release
}

J. G. Droppo, Jr.

July 2004

Prepared for the U.S. Department of Energy under Contract DE-AC06-76RL01830 


\title{
DISCLAIMER
}

This report was prepared as an account of work sponsored by an agency of the United States Government. Neither the United States Government nor any agency thereof, nor Battelle Memorial Institute, nor any of their employees, makes any warranty, express or implied, or assumes any legal liability or responsibility for the accuracy, completeness, or usefulness of any information, apparatus, product, or process disclosed, or represents that its use would not infringe privately owned rights. Reference herein to any specific commercial product, process, or service by trade name, trademark, manufacturer, or otherwise does not necessarily constitute or imply its endorsement, recommendation, or favoring by the United States Government or any agency thereof, or Battelle Memorial Institute. The views and opinions of authors expressed herein do not necessarily state or reflect those of the United States Government or any agency thereof.

\author{
PACIFIC NORTHWEST NATIONAL LABORATORY \\ operated by \\ BATTELLE \\ for the \\ UNITED STATES DEPARTMENT OF ENERGY \\ under Contract DE-AC06-76RL01830
}

This document was printed on recycled paper. 


\title{
Testing IH Instrumentation: Analysis of 1996-1998 Tank Ventilation Data in Terms of Characterizing a Transient Release
}

\author{
J. G. Droppo, Jr.
}

August 2004

Prepared for

the U.S. Department of Energy

under Contract DE-AC06-76RL01830

Pacific Northwest National Laboratory

Richland, Washington 99352 


\section{Summary}

An analysis is conducted of the 1996-1998 Hanford tank ventilation studies of average ventilation rates to help define characteristics of shorter term releases. This effort is being conducted as part of the design of tests of Industrial Hygiene's (IH) instrumentation ability to detect transient airborne plumes from tanks using current deployment strategies for tank operations.

This analysis has improved our understanding of the variability of hourly average tank ventilation processes. However, the analysis was unable to discern the relative importance of emissions due to continuous releases and short-duration bursts of material. The key findings are as follows:

1. The ventilation of relatively well-sealed, passively ventilated tanks appears to be driven by a combination of pressure, buoyancy, and wind influences. The results of a best-fit analysis conducted with a single data set provide information on the hourly emission variability that IH instrumentation will need to detect.

2. Tank ventilation rates and tank emission rates are not the same. The studies found that the measured infiltration rates for a single tank are often a complex function of air exchanges between tanks and air exchanges with outdoor air. This situation greatly limits the usefulness of the ventilation data in defining vapor emission rates.

3. There is no evidence in the data to discern whether the routine tank vapor releases occur over a short time (i.e., a puff) or over an extended time (i.e., continuous releases).

Based on this analysis of the tank ventilation studies, it is also noted that

- The hourly averaged emission peaks from the relatively well-sealed passively-vented tanks (such as U-103) are not a simple function of one meteorological parameter - but the peaks often are the result of the coincidence of temporal maximums in pressure, temperature, and wind influences.

- A mechanistic combination modeling approach and/or field studies may be necessary to understand the short-term temporal characteristics of transient releases; this requirement has implications in both the design of IH field tests and in understanding transient plumes during the times that worker complaints were recorded. 


\section{Acknowledgments}

This work was supported by the U.S. Department of Energy under Contract DE-AC-76RL01830 with project funding provided by CH2M HILL. Special thanks go to James Huckaby for his technical assistance and expert advice. 


\section{Contents}

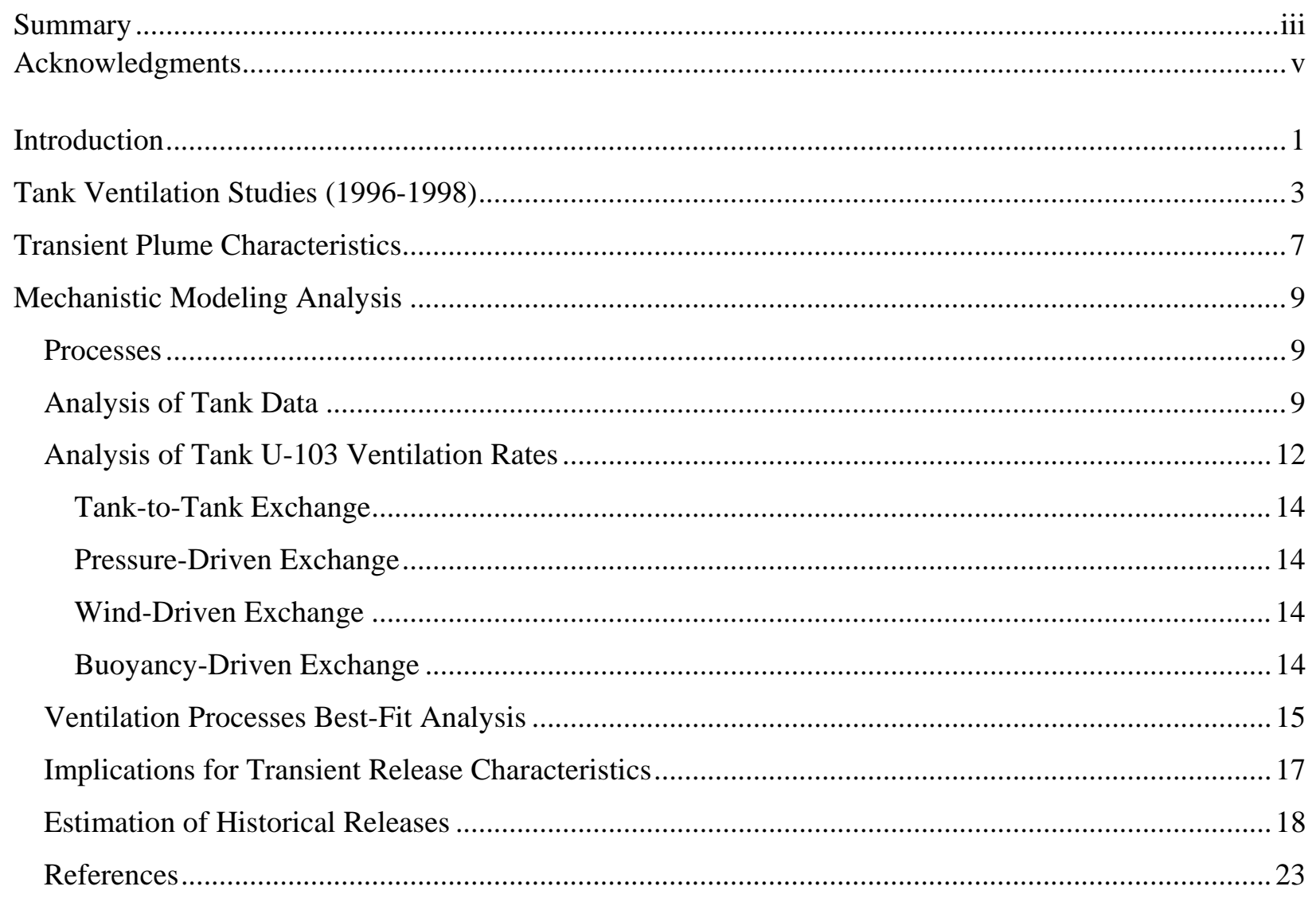




\section{Introduction}

This transmittal reports the results for two tasks: Define transient releases and Review historical release conditions. The subject tasks address characterization of tank farm releases from passively ventilated tanks to define the nature of the tests.

This project has the overall objective of testing to determine the capability of the current Industrial Hygiene (IH) instrumentation. Sensitivity testing and transient response testing are included. This testing program has been initiated as part of CH2M HILL's work to address concerns regarding worker exposures to vapors. This testing will help resolve an apparent disconnect between what workers smell (i.e., complaints) and what the instrumentation detects.

The efforts reported are to help us understand how we should challenge the IH instrumentation during testing. Information is reviewed on the potential nature of transient releases. Implications for comparisons with historical worker complaint events in terms of the potential for transient plume releases are also considered.

If a release rate can be defined for the venting of a tank to the ambient air, then concentrations of vapors in the headspace, as given in Stock and Huckaby (2000), can be used to define emission rates for specific vapors of interest. The volume of air in the tank headspace is projected to be relatively small such that releases will disperse quickly in the atmosphere. Time periods with higher exchange rates will have the same exhaust concentrations as time periods with lower exchange rates. The greater volume of release for the higher exchange means that more material is being released, and as a result the plume will tend to maintain higher concentrations for greater distances - and thus have a greater chance of being detected farther from the release point. Field tests will need to consider expected dispersion of the released material under different stability and wind conditions.

This work considers the potential characteristics of transient releases from passively ventilated tanks. Some tanks have mechanical exhausters that are designed to produce ventilation rates in the 100s of $\mathrm{m}^{3} / \mathrm{hr}$. For such tanks, meteorological effects will have second-order or less influence on the ventilation rates, and the vapor emissions can be characterized by a combination of forced ventilation rates and vapor concentrations in the headspace.

Studies were reviewed from the time-period 1996-1998 that defined the ventilation rates of the headspace volumes of the tank farms. These reported data are analyzed below, along with the hourly meteorological data from the Hanford Meteorological Station. Our aim is to better understand the mechanisms driving the transient releases. The relative importance of atmospheric processes that are potentially controlling the ventilation rates is also studied. 


\section{Tank Ventilation Studies (1996-1998)}

A series of field tests were conducted during 1996-1998 to determine the ventilation rates of individual Hanford tanks (Huckaby et al. 1997, 1998). For passively vented tanks, approximately 40 tests were conduced on 11 different tanks. A brief summary of those tests is given here. The reader is referred to the subject reports for a more detailed discussion of analysis methods, equations, and results.

The test procedure was to inject some amount of tracer gas into a tank headspace sufficient to increase the headspace concentrations of the tracer to well over background levels. Because the head space tracer concentrations decrease over time because of the tank ventilation, the rates of tank ventilation could be computed from the measured tracer concentrations at the beginning and end of each of the test periods.

A summary of the tests and results is provided in Table 1, which lists tanks tested, test dates, number of days in each test period, ventilation rate, and tracer. Note that most of the test periods are a test series based on one injection of a tracer. Two tracers were used: sulfur hexafluoride $\left(\mathrm{SF}_{6}\right)$ and helium (He). Some tests were conducted with two tracers. These studies found that $\mathrm{SF}_{6}$ losses appeared to work for some tanks and not for others. $\mathrm{SF}_{6}$ did provide comparable results for Tank U-103, and the average values for both tracers are listed for some study periods. The other values are listed as found in the referenced reports.

The computed average ventilation rates vary from 1.7 to $42 \mathrm{~m}^{3} / \mathrm{hr}$. Figure 1 shows the observed rates ranked from highest to lowest. A few study periods had higher ventilation rates but most periods had rates of less than $10 \mathrm{~m}^{3} / \mathrm{hr}$.

The measured ventilation rates for tanks with underground connections to other tanks were found to include air exchanges with the other tanks. That is, a decrease in tracer concentrations in one tank was the result of air exchanges to the atmosphere and of air exchanges with other connected tanks. As a result, for interconnected tanks the emissions to the atmosphere cannot be simply computed using the measured ventilation rates.

If the tanks with higher ventilation rates shown in Figure 1 represent air exchanges with outdoor air, then these types of tanks would be strong candidates for transient releases with higher vapor concentrations. However, with the complication of the exchanges between tanks, it is uncertain if these higher ventilation rates can be interpreted in terms of potential emission rates. To underscore this issue, the ventilation studies included measurements at one tank where the internal exchange was sufficiently dominant that meaningful exchange rates could not be computed from the measurements (Huckaby et al. 1998). 
Table 1. List of Hanford Tank Ventilation Tests Conducted 1996-1998 (from Huckaby et al. 1997 and Huckaby et al. 1998

\begin{tabular}{|c|c|c|c|c|c|c|}
\hline Test No. & Tank & Test Start & Test End & $\begin{array}{c}\text { Test } \\
\text { Duration Days }\end{array}$ & $\begin{array}{l}\text { Ventilation } \\
\text { Rate, } \mathbf{m}^{3} / \mathbf{h r}\end{array}$ & Tracer \\
\hline 1 & A-101 & 9-Jul-97 & 15-Jul-97 & 6 & 17.0 & He \\
\hline 2 & AX-102 & 8-Aug-97 & 2-Sep-97 & 25 & 34.0 & H” \\
\hline 3 & AX-102 & 2-Sep-97 & 8-Sep-97 & 6 & 23.0 & $\mathrm{He}$ \\
\hline 4 & AX-103 & 25-Feb-97 & 2-Mar-97 & 5 & 42.0 & $H^{\prime \prime}$ \\
\hline 5 & BY-105 & 17-Apr-97 & 23-Apr-97 & 6 & 36.0 & $\mathrm{He}$ \\
\hline 6 & BY-105 & 23-Apr-97 & 8-May-97 & 15 & 21.0 & $\mathrm{SF}_{6}$ \\
\hline 7 & C-107 & 21-Feb-97 & 27-Feb-97 & 6 & 2.4 & $\mathrm{He}$ \\
\hline 8 & C-107 & 27-Feb-97 & 21-Mar-97 & 22 & 1.7 & $\mathrm{He}$ \\
\hline 9 & S-102 & 24-Sep-96 & 30-Sep-96 & 6 & 5.7 & $\mathrm{He}$ \\
\hline 10 & S-102 & 24-Sep-96 & 30-Sep-96 & 6 & 3.3 & $\mathrm{SF}_{6}$ \\
\hline 11 & S-102 & 30-Sep-96 & 11-Oct-96 & 11 & 2.2 & $\mathrm{He}$ \\
\hline 12 & S-102 & 30-Sep-96 & 11-Oct-96 & 11 & 3.1 & $\mathrm{SF}_{6}$ \\
\hline 13 & S-102 & 11-Oct-96 & 19-Dec-96 & 69 & 4.1 & $\mathrm{SF}_{6}$ \\
\hline 14 & S-102 & 19-Dec-96 & 11-Feb-97 & 54 & 3.5 & $\mathrm{SF}_{6}$ \\
\hline 15 & TX-104 & 14-Jan-98 & 22-Jan-98 & 8 & 6.0 & $\mathrm{He}$ \\
\hline 16 & TX-104 & 22-Jan-98 & 12-Feb-98 & 21 & 5.9 & $\mathrm{He}$ \\
\hline 17 & U-102 & 9-Jan-98 & 15-Jan-98 & 6 & 3.0 & $\mathrm{He}$ \\
\hline 18 & U-102 & 15-Jan-98 & 13-Feb-98 & 29 & 4.8 & $\mathrm{He}$ \\
\hline 19 & U-102 & 13-Feb-98 & 24-Mar-98 & 39 & 2.7 & $\mathrm{He}$ \\
\hline 20 & U-103 & 27-Feb-97 & 6-Mar-97 & 7 & 4.9 & He and $\mathrm{SF}_{6}$ \\
\hline 21 & U-103 & 6-Mar-97 & 31-Mar-97 & 25 & 4.0 & $\mathrm{He}$ and $\mathrm{SF}_{6}$ \\
\hline 22 & U-103 & 31-Mar-97 & 9-Apr-97 & 9 & 5.2 & $\mathrm{He}$ and $\mathrm{SF}_{6}$ \\
\hline 23 & U-103 & 9-Apr-97 & 28-May-97 & 49 & 2.6 & $\mathrm{SF}_{6}$ \\
\hline 24 & U-103 & 28-May-97 & 14-Jul-97 & 47 & 2.2 & $\mathrm{SF}_{6}$ \\
\hline 25 & U-103 & 15-Jul-97 & 22-Jul-97 & 7 & 3.5 & $\mathrm{He}$ and $\mathrm{SF}_{6}$ \\
\hline 26 & U-103 & 22-Jul-97 & 13-Aug-97 & 22 & 2.4 & $\mathrm{He}$ \\
\hline 27 & U-103 & 13-Aug-97 & 1-Oct-97 & 49 & 2.2 & $\mathrm{He}$ \\
\hline 28 & U-103 & 1-Oct-97 & 18-Nov-97 & 48 & 3.4 & $\mathrm{He}$ \\
\hline 29 & U-103 & 18-Nov-97 & 15-Dec-97 & 27 & 4.3 & $\mathrm{He}$ \\
\hline 30 & U-103 & 15-Dec-97 & 8-Jan-98 & 24 & 3.6 & $\mathrm{He}$ \\
\hline 31 & U-105 & 18-Jul-97 & 24-Jul-97 & 6 & 7.4 & $\mathrm{He}$ \\
\hline 32 & U-105 & 24-Jul-97 & 15-Aug-97 & 22 & 8.8 & $\mathrm{He}$ \\
\hline 33 & U-106 & 9-Jan-98 & 15-Jan-98 & 6 & 2.5 & $\mathrm{He}$ \\
\hline 34 & U-106 & 15-Jan-98 & 13-Feb-98 & 29 & 2.2 & $\mathrm{He}$ \\
\hline 35 & U-106 & 13-Feb-98 & 24-Mar-98 & 39 & 2.1 & $\mathrm{He}$ \\
\hline 36 & U-111 & 9-Jan-98 & 15-Jan-98 & 6 & 4.8 & $\mathrm{He}$ \\
\hline 37 & U-111 & 15-Jan-98 & 13-Feb-98 & 29 & 3.5 & $\mathrm{He}$ \\
\hline 38 & U-111 & 13-Feb-98 & 24-Mar-98 & 39 & 2.7 & $\mathrm{He}$ \\
\hline
\end{tabular}


Observed Ventilation Rates

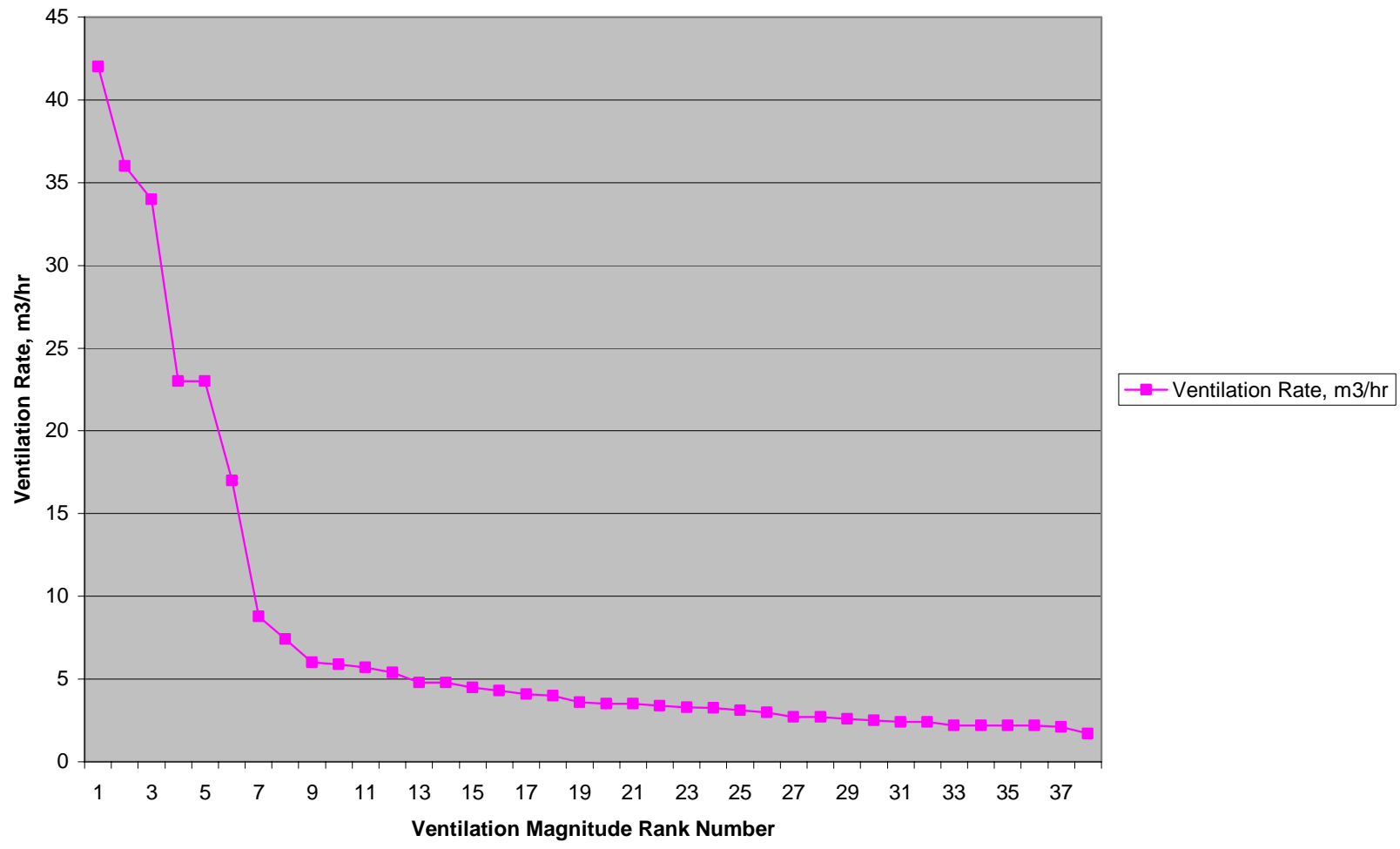

Figure 1. Ranked Range of Observed Tank Ventilation Rates 


\section{Transient Plume Characteristics}

The characteristics of a transient plume are not well defined. Descriptions vary from a short "whiff” of material to extended periods with an odd smell. The most perplexing are the very short-duration sensory events. The possible source of the material may be anything from a short-duration release to the meandering plume of a continuous release. The uncertain nature of a transient plume makes design of the IH instrumentation tests difficult.

A "transient plume" could be a continuous release that creates a plume that meanders and makes detection difficult - and results in short-duration sensing of the plume at a specific location. For such a continuous release, then, some persistence (or reoccurrence) of the observations of smell over time would be expected; it appears that some tanks do have smells that have this property.

A "transient" plume also could be a release with short-time duration, which is often referred to as a puff release. The one-time nature of many of the reported worker observations of smells is what might be expected from a puff or short-duration release. However, we found no evidence that a transient plume is clearly the result of one or the other of these types of releases. It is very possible that observed transient plumes include examples of both types of release. 


\section{Mechanistic Modeling Analysis}

These tank-to-air exchange processes are used as the basis for a mechanistic modeling analysis of the ventilation rates described above in the 1996-1998 studies.

\section{Processes}

Everything that happens in nature requires energy to occur; this is also true of the ventilation of the tank headspace volumes. There will be an exchange between the atmosphere and the headspaces only to the extent that there is energy to drive that exchange. Table 2 summarizes the mechanisms along with their implications for resultant transient release characteristics. The sources of ventilation energy that we identified are:

- Active venting - The tank is under negative pressure as headspace gases are drawn out with a fan.

- Atmosphere-tank air-density differences - Buoyancy effects will tend to induce air exchange when the headspace air is lighter (e.g., warmer) than ambient air.

- Ambient air pressure changes - As the ambient atmospheric pressure rises and falls, the pressure difference between the tank headspace and atmosphere re-equilibrates by transferring air into or out of the headspace.

- Wind-driven circulation - Differential pressures on vents can drive tank ventilation. This mechanism may be a function of wind speed and wind-speed variability, wind direction and winddirection variability, and vertical structure of the wind near the surface. From the standpoint of the vertical structure of the wind, the ambient atmospheric stability will play a major role.

Not listed are molecular and eddy diffusion, which are assumed to be negligible sources of energy for the exchange.

\section{Analysis of Tank Data}

Ventilation rates for this analysis are needed that represent only tank headspace exchanges with outdoor air. These ventilation rates are assumed to occur as the result of buoyancy (density differences), pressure changes, and winds.

The ventilation rates from all test periods are plotted in Figures 2 and 3. Figure 2 presents the ventilation rates determined for the various tanks; points are connected when there is more than one value for a tank. Figure 3 shows the same data plotted by the time of year of each study period. Figure 3 shows no obvious relationships with the time of year, which is expected because even if the ventilation rates did occur as a function of the time of year at individual tanks, the variations resulting from tank-dependent factors likely will dominate the ventilation magnitudes. Each tank, or at least some grouping of tanks, needs to be considered separately in terms of understanding how ventilation occurs. 
Table 2. Summary of Sources of Energy for Tank Ventilation Processes

\begin{tabular}{|c|c|c|c|}
\hline Energy & Mechanism & "Resultant Release Characteristics & Implications related to transient plume observations \\
\hline $\begin{array}{l}\text { Active } \\
\text { venting }\end{array}$ & $\begin{array}{l}\text { Forced air exchange } \\
\text { using fans. }\end{array}$ & Relatively constant ventilation rate. & $\begin{array}{l}\text { 1. Continuous release at all times. Intermittent sensing of this plume could } \\
\text { be the result of horizontal variations in the wind. } \\
\text { 2. Could contribute to emissions pooling under low-wind, stable conditions. }\end{array}$ \\
\hline $\begin{array}{l}\text { Atmosphere- } \\
\text { tank air- } \\
\text { density } \\
\text { differences }\end{array}$ & $\begin{array}{l}\text { Less dense (warmer) air } \\
\text { tends to rise and more } \\
\text { dense (cooler) air tends to } \\
\text { fall. The major influence } \\
\text { is the temperature } \\
\text { difference. Minor } \\
\text { influences are moisture } \\
\text { differences ( } \sim 10 \%) \text { and } \\
\text { tank gases. }\end{array}$ & $\begin{array}{l}\text { The density-driven venting energy is } \\
\text { largest during cold weather (winter) } \\
\text { and nocturnal hours. If important, } \\
\text { then diurnal and seasonal variations } \\
\text { in ventilations rates are indicated. }\end{array}$ & $\begin{array}{l}\text { 1. To the extent that the venting of a tank is though vents and other areas that } \\
\text { are constant with time, this mechanism could result in a routine release } \\
\text { that will tend to be greatest in winter and during night-time conditions. } \\
\text { 2. Operations-related tank venting will tend to increase when they are } \\
\text { conducted at times with relatively less dense tank headspace air. } \\
\text { 3. Increased venting will not necessarily occur at the location of the } \\
\text { operations, but can occur at any of the venting areas of the tank. }\end{array}$ \\
\hline $\begin{array}{l}\text { Ambient air } \\
\text { pressure } \\
\text { changes }\end{array}$ & $\begin{array}{l}\text { The tank takes in and } \\
\text { exhausts headspace air as } \\
\text { pressure rises and falls, } \\
\text { respectively. }\end{array}$ & $\begin{array}{l}\text { During frontal passes there are large } \\
\text { short time frame pressure changes } \\
\text { (one hour or less). Shorter-term } \\
\text { pressure fluctuations (such as might } \\
\text { be associated with gravity waves) } \\
\text { appear to occur infrequently at } \\
\text { Hanford. }^{\text {(a) }}\end{array}$ & $\begin{array}{l}\text { 1. Analysis of pressure-driven venting for tank indicates that the hour-to- } \\
\text { hour pressure changes are a good indicator of that venting influence. } \\
\text { 2. The greatest pressure-driven venting would be associated with the large } \\
\text { changes in pressure associated with frontal systems. The relatively short } \\
\text { time for such events could be a source of transient releases. } \\
\text { 3. Significant pressure fluctuations shorter than } 1 \text { hour in duration occur } \\
\text { very infrequently. These variations would increase the estimated hourly } \\
\text { pressure-driven ventilation by an average factor of } 2 \text { or } 3 \text {. }\end{array}$ \\
\hline $\begin{array}{l}\text { Wind-driven } \\
\text { circulation }\end{array}$ & $\begin{array}{l}\text { The energy of the wind } \\
\text { results in pressure on } \\
\text { tank-vapor exit points. }\end{array}$ & $\begin{array}{l}\text { The greatest wind-driven venting } \\
\text { would occur at higher wind speeds. } \\
\text { The wind-driven venting of tanks } \\
\text { will be a function of both wind speed } \\
\text { and wind direction - and the } \\
\text { orientation and characteristics of the } \\
\text { venting area relative to that of the } \\
\text { ambient wind. }\end{array}$ & $\begin{array}{l}\text { 1. To the extent that the wind-driven venting of a tank is through vents and } \\
\text { other areas that are constant with time, this mechanism could result in a } \\
\text { routine release that will increase as wind speed increases. } \\
\text { 2. The wind-driven venting of the tank will tend to be higher when tank } \\
\text { operations that open venting areas are conducted under higher wind } \\
\text { speeds. } \\
\text { 3. Increased venting will not necessarily occur at the location of the } \\
\text { operations, but can occur at any of the venting areas of the tank. }\end{array}$ \\
\hline $\begin{array}{l}\text { Liquid } \\
\text { to air } \\
\text { releases } \\
\text { within tanks }\end{array}$ & $\begin{array}{l}\text { Trace gases in headspace } \\
\text { air increase from gases } \\
\text { coming out of solution. }\end{array}$ & $\begin{array}{l}\text { Depends on conditions within the } \\
\text { tank - release will occur only as gas } \\
\text { comes out of solution in the tank, not } \\
\text { as the gas moves within the tank. }\end{array}$ & $\begin{array}{l}\text { 1. Internal releases involve small fractions of the volume of headspace air. } \\
\text { 2. Will be a minor influence on the density of headspace gases; may be a } \\
\text { factor in a short-term variability of vapor concentrations in the headspace } \\
\text { air. } \\
\text { 3. Will not lead to significant gas release events. }\end{array}$ \\
\hline
\end{tabular}


Exchange Rates Determined by Tracer Studies

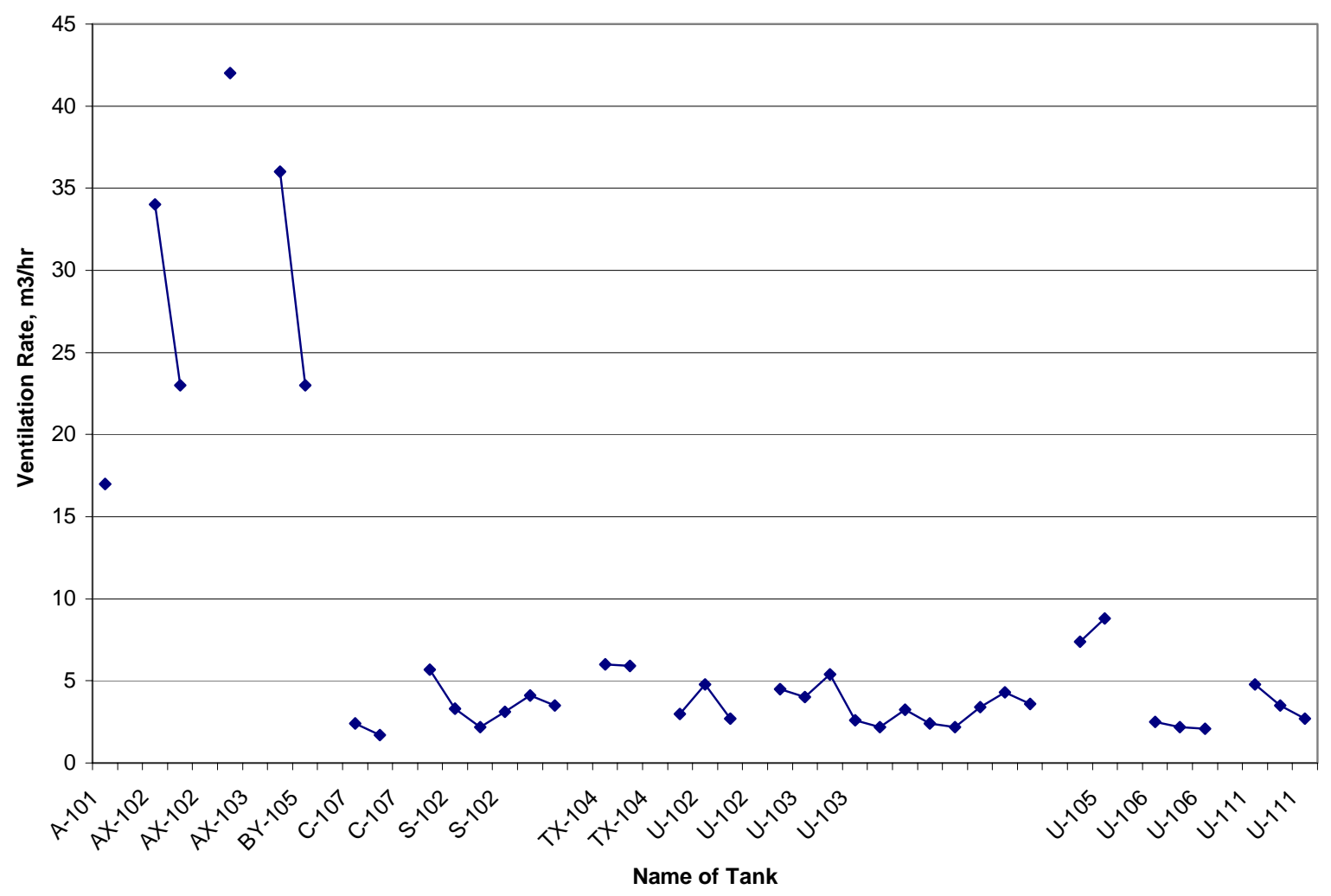

Figure 2. Ventilation Rates Determined in 1996-1998 Tracer

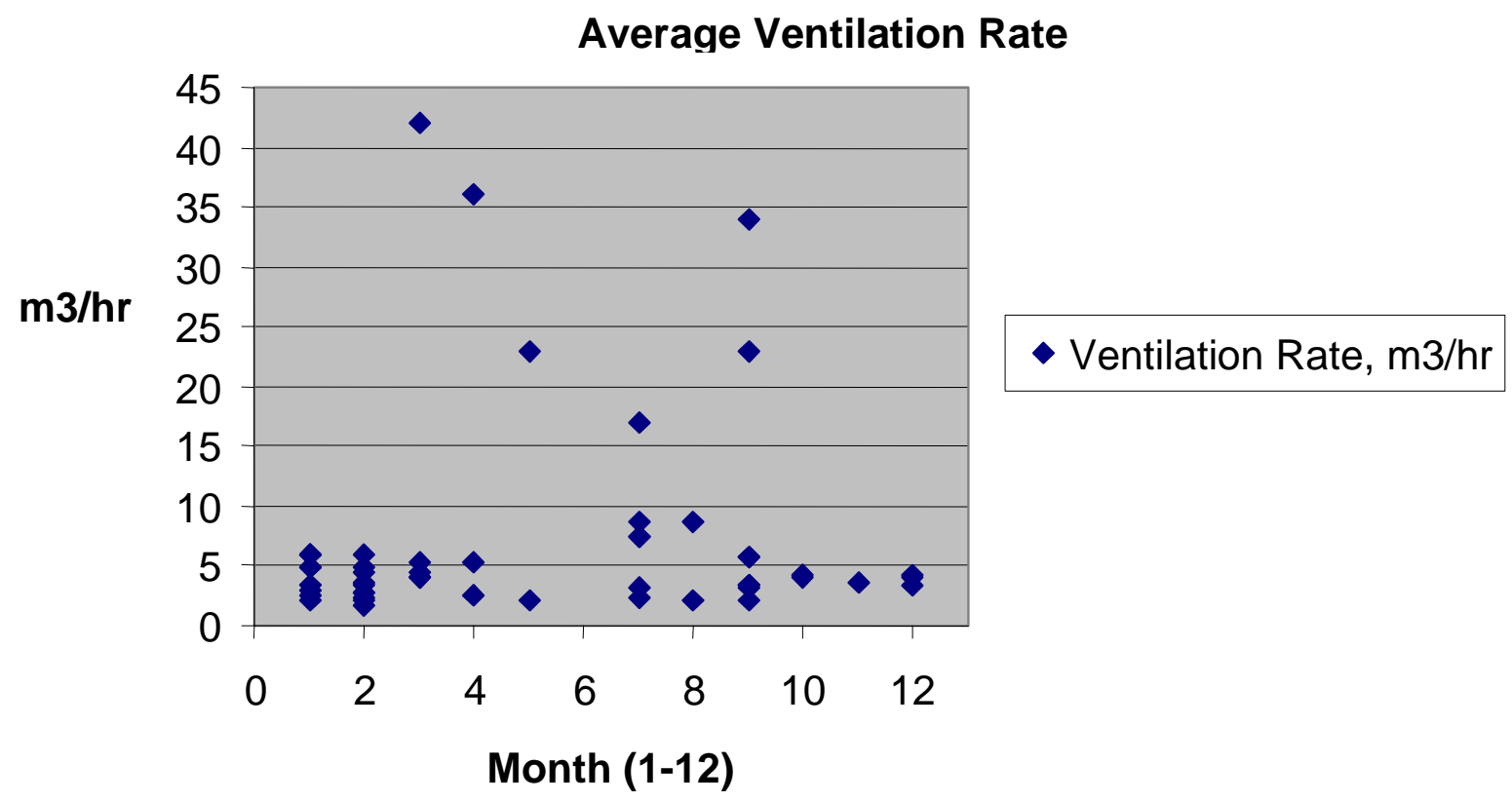

Figure 3. Ventilation Rates Plotted by Mid-Month of Study Period 
This analysis focused on determining if the tank-specific ventilation processes could be understood for single tanks or combinations of tanks. To accomplish this, ventilation-rate data for a tank are needed that show significant variability and span a range of ambient meteorological conditions.

The data considered in this analysis are the tank-ventilation data from the 1996-1998 ventilation studies and records of ambient meteorological conditions occurring during those study periods. As listed in Table 1, the ventilation measurements for those studies are averages for periods on the order of a week to several months. The challenge here is to use those data to study the importance of different ventilation processes - and relate that information to releases over much shorter time periods.

The dates and durations of the test periods are plotted for the tanks shown in Figure 4. Tank U-103 spans four seasons and has the greatest number of study periods. That tank does show significantly different measured ventilation rates. That is, there is about a 2.5 -times variation in the ventilation rates (see Table 1) compared to the 10-20 percent measurement resolution reported in these studies. These factors make Tank U-103 the best candidate for studying the relative importance of varying ventilation influences.

The published data from Tank S-102 are also a candidate for analysis. The reported ventilation rates have a sufficient range that some differentiation by ambient conditions may also be possible. Other tanks with more than one test period may provide some limited ventilation information. Also the 1999 tracer studies of Tank S-106 provides several months of short-duration measurements (approximately every five minutes) that may, when combined with local climatology records, provide valuable information on the influences on hourly venting rates (Huckaby et. al. 1999).

\section{Analysis of Tank U-103 Ventilation Rates}

The following section analyzes the Tank U-103 results. To glean information on the relative importance of processes that drive the ventilation of the tank headspace volumes, the analysis requires ventilation data for specific tanks with sufficiently large variations in both the ventilation rates and the ambient conditions.

A correction is applied to the measured rates to account for the effect of tank-to-tank air exchanges. The correction assumes a two-way exchange between the tanks that stabilizes in time, with both tanks eventually having the same tracer concentrations. For each time period, the portion of the tracer-derived ventilation rates estimated to be the result of air exchanges with Tank U-102 is subtracted from the observed rate for Tank U-103. The correction is based on the assumption that the tanks ventilate in a similar manner and have some rate of exchange between them. During the study periods, the tracer concentrations increase with time in Tank U-102 up to the point where they are equal to the concentrations in Tank U-103. The rate amount of tracer-spiked air going from Tank U-103 to Tank U-102 is required to explain how the increase in Tank U-102 was computed and subtracted from the measured exchange rate. Hourly winds and temperature data from the Hanford Meteorology Station were used to compute the relative energy in ambient wind and buoyancy influences for each of the study time-periods. 


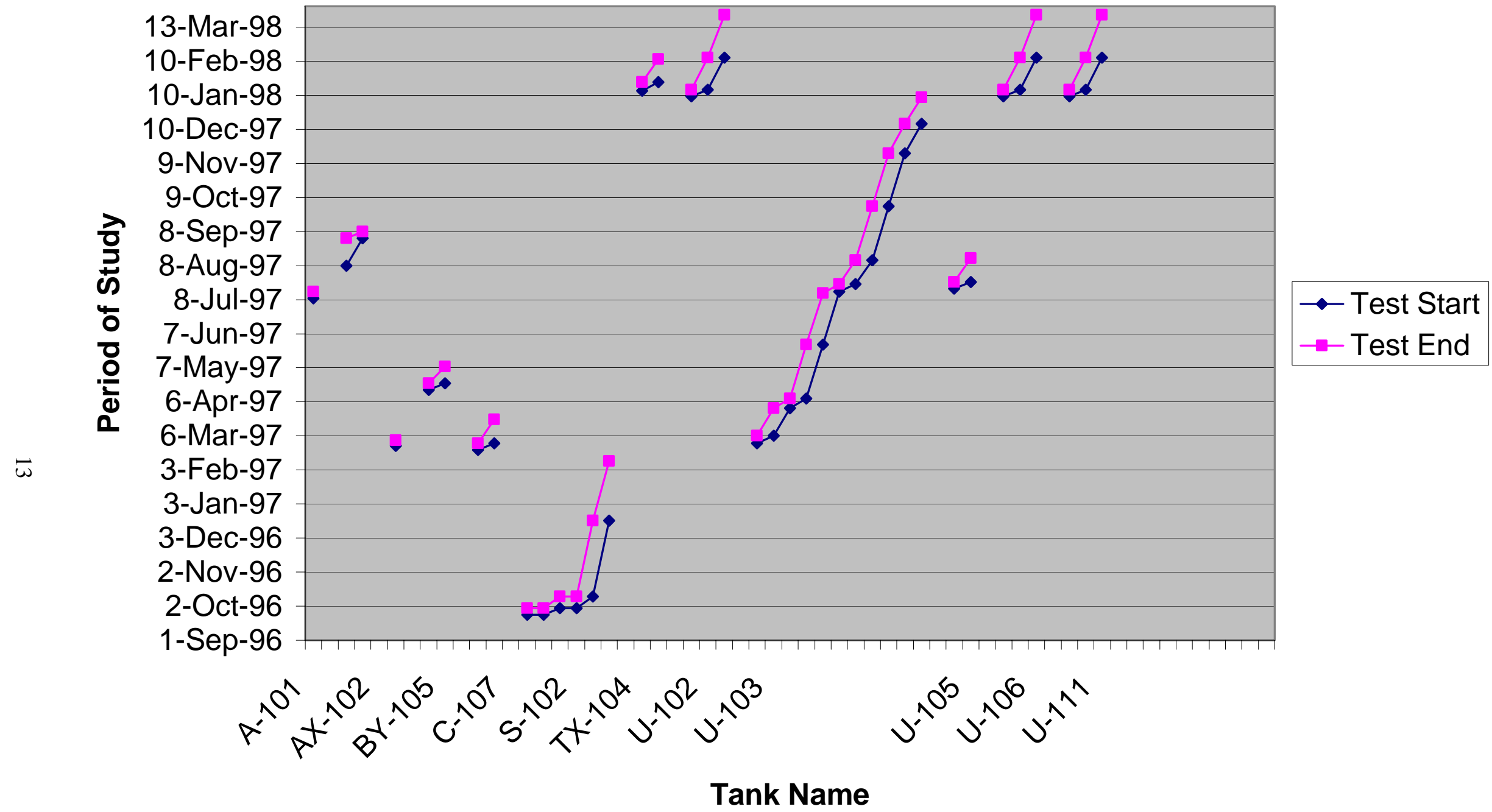

Figure 4. Hanford Tank Ventilation Studies, 1996-1998 


\section{Tank-to-Tank Exchange}

Ventilation rates are needed that represent exchanges with outdoor air alone. The reported ventilation rates for Tank U-103 are a combination of exchanges with a nearby tank and with the ambient air (Huckaby et al. 1998). The studies of the exchange rates between these tanks show that the influence of tank-to-tank exchanges on the reported ventilation rates will vary with time after the initial injection of tracer. The first study period has the largest tracer concentration differences between the tanks with the difference progressively decreasing with time. These changes in observed concentration differences between the tanks allow an estimation of the magnitude of the tank-to-tank ventilation rate and thus allow subtraction of that estimated rate from the reported rate to give the outdoor ventilation rate. This procedure was conducted for each of the periods with reported ventilation rates for Tank U-103. The corrected ventilation rates used in the analysis reported below are only slightly lower than the reported rates. ${ }^{(a)}$

\section{Pressure-Driven Exchange}

The pressure-driven gas exchanges are computed based on the equation-of-state using hourly pressure data from the Hanford Meteorological Station. The hourly rates of pressure-induced exchange rates can be computed directly from the tank characteristics and magnitude of the pressure change. When the ambient atmospheric pressure is falling, there will be airflow out of the tank. When pressure rises, the airflow is into the tank (and there is no pressure-related emission of headspace vapors).

The observed ventilation rates are greater than can be explained by pressure changes alone. The residual portion of the ventilation (the portion left once the pressure-related exchanges are removed) is assumed here to be the result of other processes such as wind- and buoyancy-driven gas exchanges.

\section{Wind-Driven Exchange}

The kinetic energy contained in the wind is represented as the sum of the square of the average wind speed (from the Hanford Meteorological Station surface observations) for all the hours during a test period. The average kinetic energy per unit volume is computed as the average of the hourly wind speeds squared $\left(1 / 2 \mathrm{~m} \mathrm{v}^{2}\right)$ for each hour of a tracer ventilation test, where $\mathrm{m}$ is the mass in $1 \mathrm{~m}^{3}$ of air and $\mathrm{v}$ is the wind speed.

\section{Buoyancy-Driven Exchange}

The buoyancy term is computed as the sum of the hourly positive potential energy available to drive an air exchange. The buoyancy is based on the density difference between the air in the tank headspace and outdoor air. The air temperature from Hanford Meteorological Station is used as the outdoor temperature. Headspace temperatures for Tank U-103 were obtained from the TWINS data.

(a) Only the studies of Tank-103 provide the data needed to characterize the tank-to-tank exchanges. Data for addressing the issue of internal tank-to-tank air exchanges were not collected for other tanks. 
The effect of moisture content on the buoyancy of the tank air is included. The headspace is assumed to be saturated. The relative humidity measured at the Hanford Meteorological Station was used for outdoor air. The inclusion of moisture effects on density resulted in small changes in the computed buoyancy: less than 1 percent change under winter conditions and between 10 to 20 percent increase under summer conditions. We also assumed that the release of gases within the tank was not a factor in terms of the density of the gases in the headspace volume. ${ }^{(a)}$

\section{Ventilation Processes Best-Fit Analysis}

A best-fit analysis was conducted to determine what combination, if any, of the variations in wind and buoyancy influences could best explain the observed variability in ventilation rates. The following empirical relationship is used to study the overall importance of the processes potentially controlling the tank ventilation rates:

$$
\mathrm{V}_{\mathrm{t}}=\mathrm{V}_{\mathrm{p}}+\mathrm{m}(\mathrm{K} \mathrm{b}+\mathrm{B}(\mathrm{b}-1))
$$

where

$$
\begin{aligned}
& \mathrm{V}_{\mathrm{t}}=\text { average tank atmosphere ventilation rate, } \mathrm{m}^{3} / \mathrm{hr} \\
& \mathrm{V}_{\mathrm{p}}=\text { average hourly pressure-derived exhaust rate, } \mathrm{m}^{3} / \mathrm{hr} \\
& \mathrm{K}=\text { average hourly wind-derived kinetic energy per unit volume, Joule/m } / \mathrm{m}^{3}-\mathrm{hr} \\
& \mathrm{B}=\text { average hourly buoyancy-derived energy per unit volume, Joule/m3-hr } \\
& \mathrm{m}=\text { an empirical constant, } \mathrm{m}^{6} / \text { Joule } \\
& \mathrm{b}=\text { a dimensionless constant in the range of } 0 \text { to } 1 .
\end{aligned}
$$

This empirical relationship assumes that after accounting for ventilation resulting from pressure changes, the remaining portion of a measured ventilation rate is driven by some combination of wind and/or buoyancy influences. The constant, b, represents the relative importance the wind and buoyancy influences for a specific tank. The constant $m$ is a measure of the usage of the energies available to drive ventilation. Thus, the constants $\mathrm{m}$ and $\mathrm{b}$ may be considered together to represent energy utilization efficiency for ventilation of the tank headspace. These constants specify how effective ambient wind and buoyancy energies will be in driving tank ventilation rates.

This formulation can be generalized for applications to additional tanks by including factors such as the headspace volume, area, vent characteristics, etc. Rewriting the above equation with separate buoyancy and wind empirical constants $C_{k}$ and $C_{b}$, respectively (i.e., $V_{t}=V_{p}+C_{k} K+C_{b} B$ ) will facilitate the inclusion of tank-specific properties. Although the specific mechanisms driving tank ventilation should not be expected necessarily to be directly proportional to the available energies, the relative proportioning of importance of the influences is expected to be the same.

(a) For example, releases of $\mathrm{H}_{2}$ (a lighter-than-air gas) from the waste have been observed to raise the headspace $\mathrm{H}_{2}$ concentration to about 6000 ppm under certain conditions in a passively vented tank. This represents only a 0.6 percent decrease in the density of headspace air. 
The procedure is to match the overall estimated and measured exchange rates using the parameter $\mathrm{m}$ and find the value of $b$ between 0 and 1 that provided the best fit of the individual estimated and measured exchange rates (using the criterion of smallest value of the sum of the square of the difference between estimated and measured values). Several iterations of the procedure are required to find the best match of the overall estimated and measured exchange rates.

The results of this best-fit analysis of wind and buoyancy influences are shown in Figures 5 and 6 . The tests were conducted in sequence over 1 year, such that these plots represent approximately one annual cycle (starting in January). There is a close match between measured and computed ventilation rates (Figure 5), and the pressure, buoyancy, and wind influences all play a role (Figure 6). The mean of the square of the differences between the measured and computed ventilation rates is $0.45 \mathrm{~m}^{3} / \mathrm{hr}$. Using buoyancy and wind terms alone in a best-fit analysis gives mean values of the square of the differences of 2.5 and $0.91 \mathrm{~m}^{3} / \mathrm{hr}$, respectively. The pressure-driven volume changes, which are computed directly from observations and tank characteristics, are only a small fraction of the total measured ventilation rates. The individual pressure, buoyancy, and wind curves in Figure 6 do not track the measured ventilation curve shown in Figure 5.

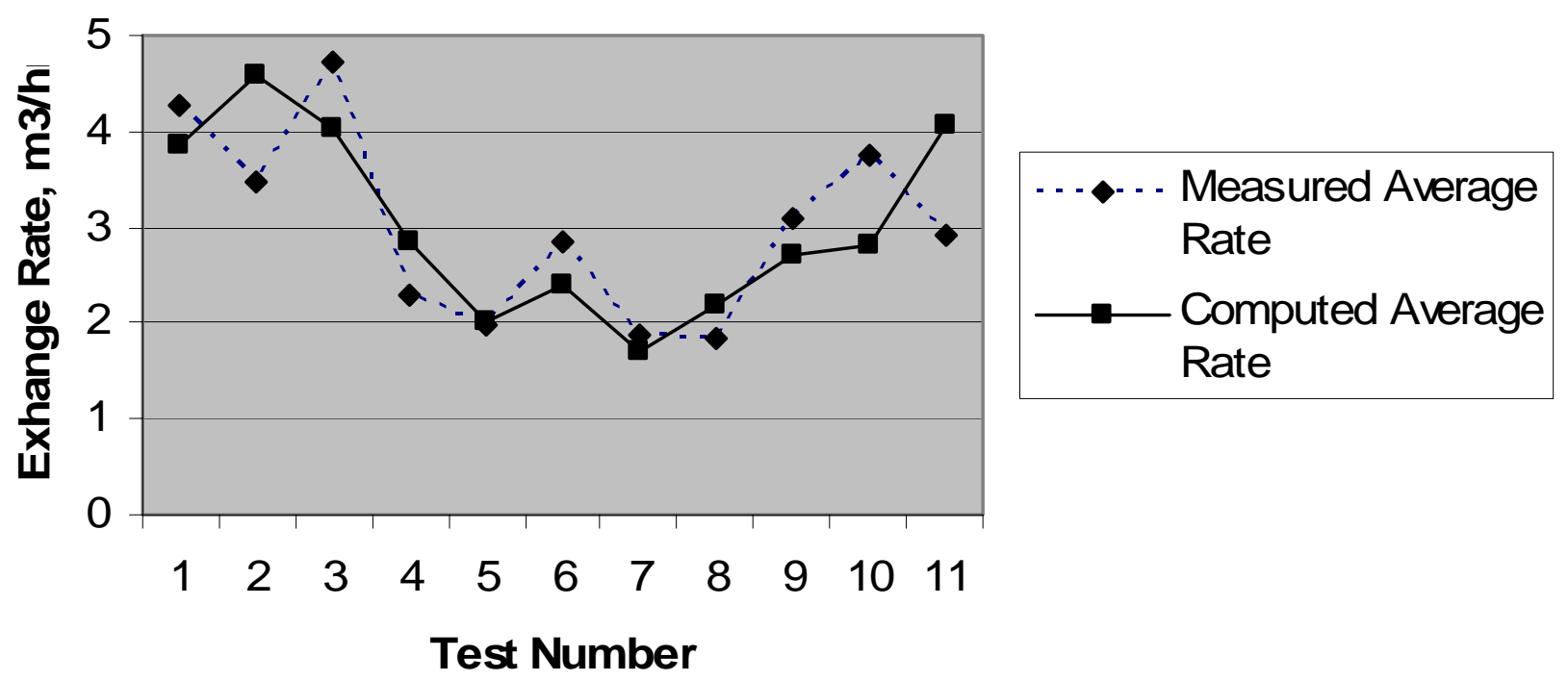

Figure 5. Comparison of Measured and Computed Air Exchange Rates for Tank U-103

In this best-fit result, pressure, buoyancy, and wind influences contributed on average 10 percent, 30 percent, and 60 percent, respectively, to the total ventilation rates. The average pressure contributions to ventilation are small and about the same magnitude during different seasons. The manner in which the average influences of wind and buoyancy changed during the tests at different times of the year is evident and follows what would be physically expected. That is, the buoyancy term has its greatest influence when outdoor temperatures are lower. 


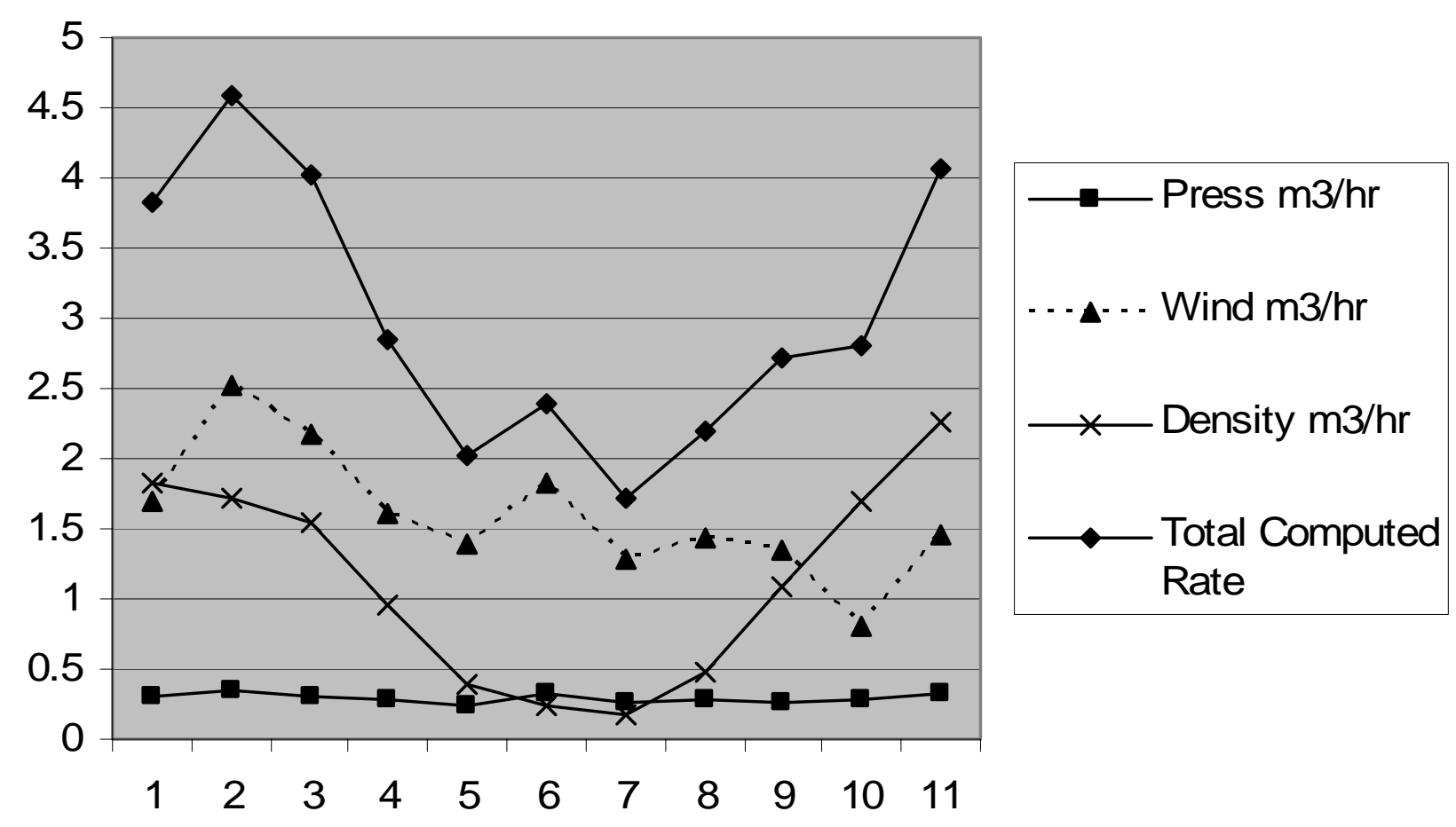

Figure 6. Influence on Average Ventilation During Field Test Study Periods

These results must be viewed with some caution in terms of their generality. They apply only to Tank U-103 and perhaps only to the studied time periods. The overall averages of the computed rates are equal to the measured rates because that equality is assumed. Although the temporal variations in average ventilation rates are closely matched, no independent check has been made of the relationship.

This analysis is based on the assumption that only pressure, buoyancy, and wind are significant influences on the tank ventilation rates. The possibility needs to be considered that there may be other controlling influences that could vary in a similar manner. For example, parameters that affect ventilation such as tank access activities could have varied with season during these studies. Additional studies on other tanks with measured tank ventilation rates will be useful in defining the validity and generality of these preliminary results.

\section{Implications for Transient Release Characteristics}

Although the results show that the variability in measured average ventilation rates are best explained by combinations of pressure, buoyancy, and wind influences, these results represent averages for the test periods; they do not provide information on the hour-to-hour variability in the importance of these influences.

Hourly release rates equivalent to the measured release rates during the study period at Tank U-103 can be computed using the hourly observations in pressure, temperatures, and winds. Figures 7 and 8 are illustrative examples using Tank U-103 study periods 1 and 6 (listed as test numbers 17 and 25 in Table 1). These plots show the projected variability in tank ventilation rates during seven days of winter and summer conditions, respectively, using 1997 Hanford Meteorological Station observations. 
Extrapolation is made to two additional winter and summer time periods (assuming similar average ventilation rates and relative importance of wind and temperature influences as shown in Figures 7 and 8). These results (Figures 9 and 10) provide additional insight to the implied hourly variations in ventilation rates.

Figures 7 to 10 illustrate the expected hourly variability assuming the balance of the influences identified in the analysis of the Tank U-103 tracer tests discussed above. Similar season-specific characteristics are seen in the plots for winter (Figures 7 and 9) and summer (Figures 8 and 10). The hourly exchange rates in Figures 7 to 10 show minimums and maximums in ventilation rates. Although the total ventilation rates often occur as the result of combined effect of the wind, buoyancy, and pressure influences, the selected periods tend to have peak ventilation rates as the result of the influence of winds. These plots also illustrate occurrences of episodic times for peak ventilation rates that in several places tend to have a diurnal cycle.

\section{Estimation of Historical Releases}

A means of estimating tank ventilation rates as a function of ambient conditions will be useful in understanding potential historical releases and studying correlations between worker reports of odors and the ambient meteorology.

Parameters and procedures for comparisons have been developed. Although a comparison with historical complaint events is outside the scope of this task, these results help define appropriate parameters for comparing tank characteristics. In terms of conducting comparisons between complaints and potential tank ventilation mechanisms, the major issues to be addressed are:

- Importance of atmospheric dispersion processes - An expert inspection of the types of meteorological conditions and locations where the historical complaints have been registered may provide insight to type of release. For example, a grouping by atmospheric stability during the times of complaints will indicate if atmospheric dispersion rates are an important factor.

- Tank ventilation rates - Compare the historical complaint events with parameters representing tankspecific, or tank-type, combined influences of (1) pressure changes, (2) buoyancy, and (3) winds impacting the ventilation ports of the tanks. This combined parameter approach recommendation is based on the analysis of the 1996-1998 tank ventilation studies given above.

- Tank vapor emission pooling - Look at the nocturnal and early morning subset of cases to see if there is any evidence of pooling (i.e., local storage of released material by local topographic depressions). Note that this mechanism only applies to specific areas at a few of the tank farms. The location of the complaint will need to be in the vicinity of the area - but not necessarily at the specific tank that is the origin of the emissions.

The design of IH instrumentation field tests should account for the possibility that ventilation peaks tend to be the result of the cumulative effect of multiple factors. A basis was developed for generating parameters that represent the major influences on tank ventilation on an hourly basis. This approach will 


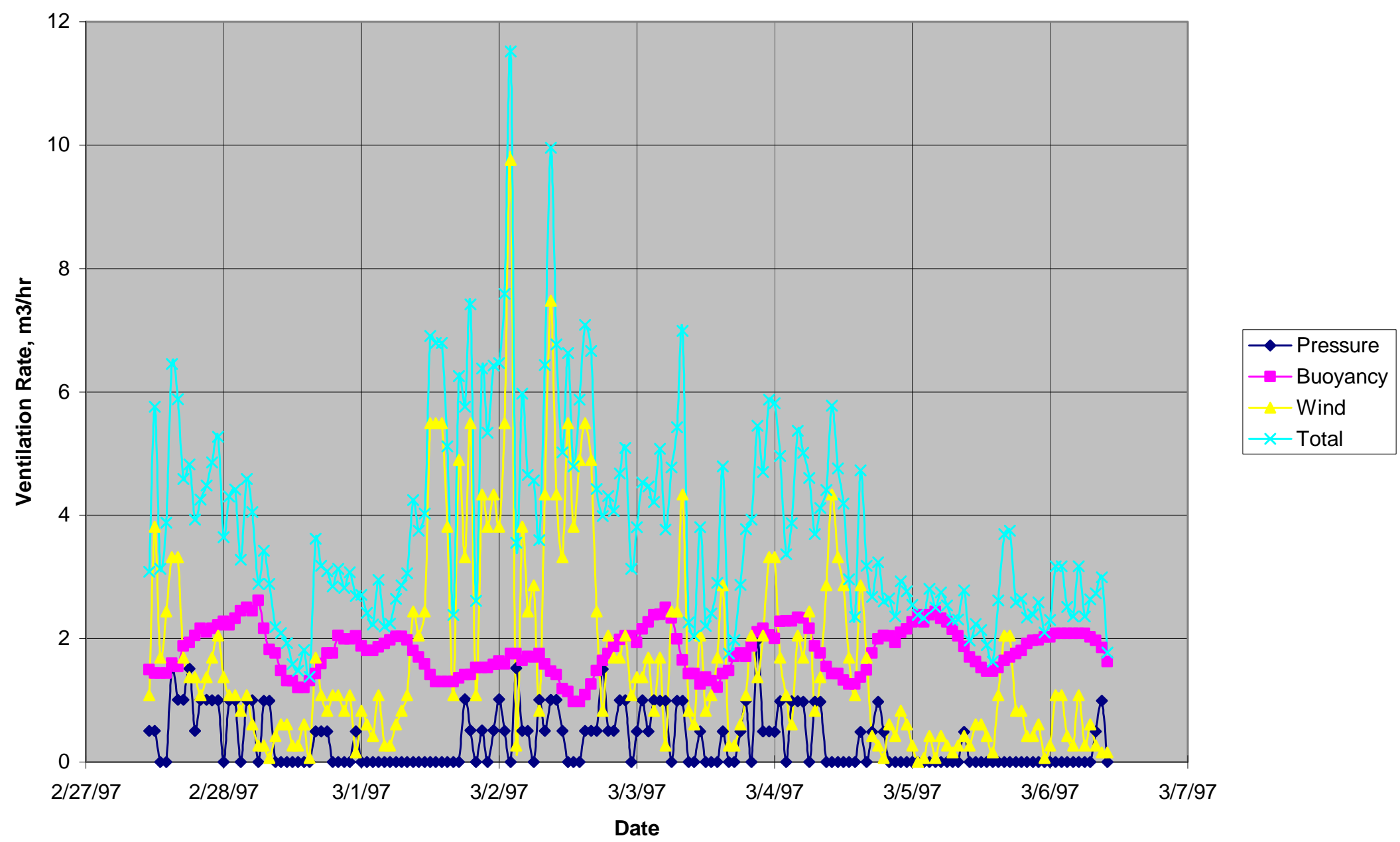

Figure 7. Projected Hourly Tank Ventilation Rates in Tank U-103 During a Winter Tracer Study Period 


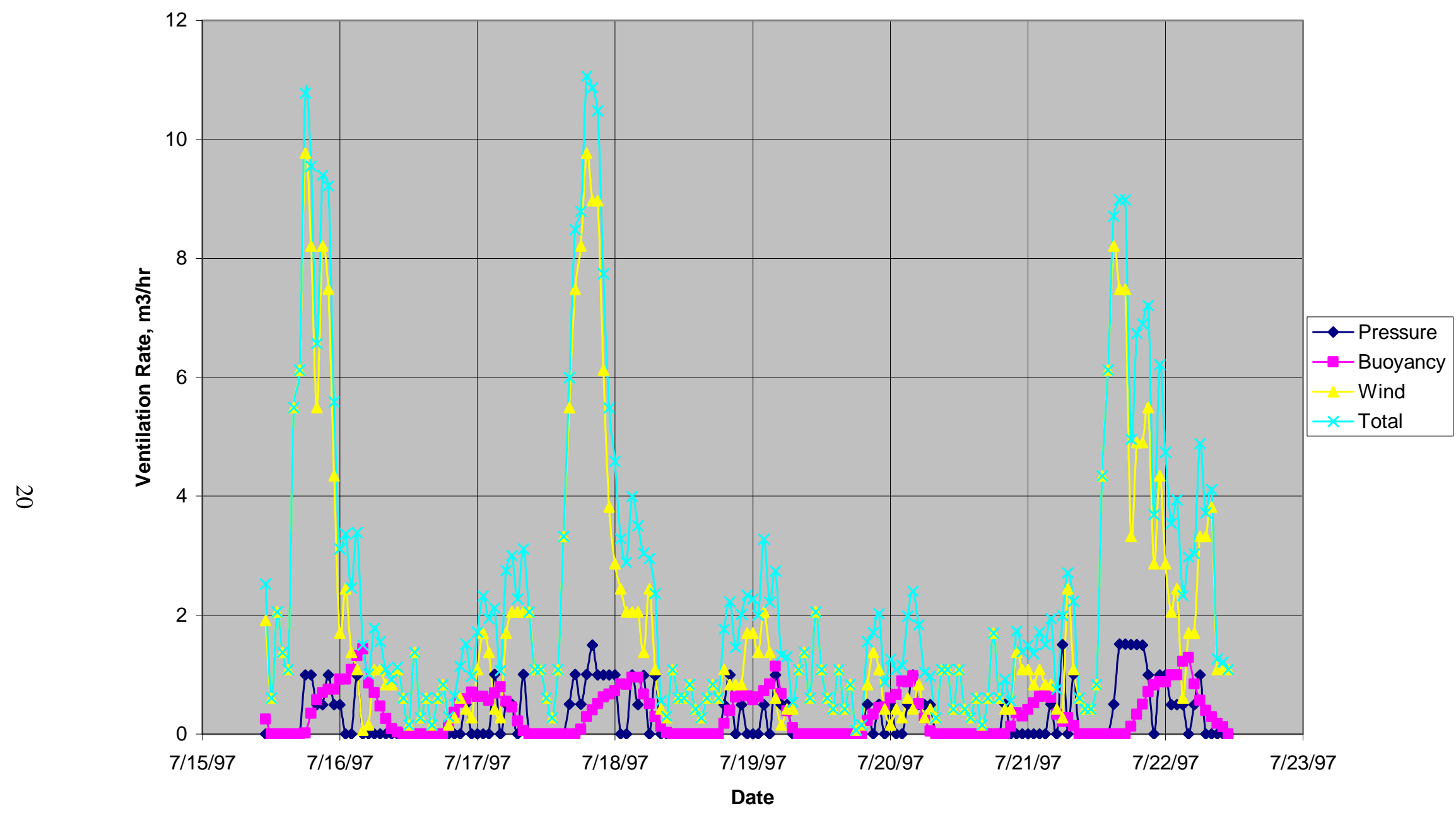

Figure 8. Projected Hourly Tank Ventilation Rates in Tank U-103 During a Summer Tracer Study Period 


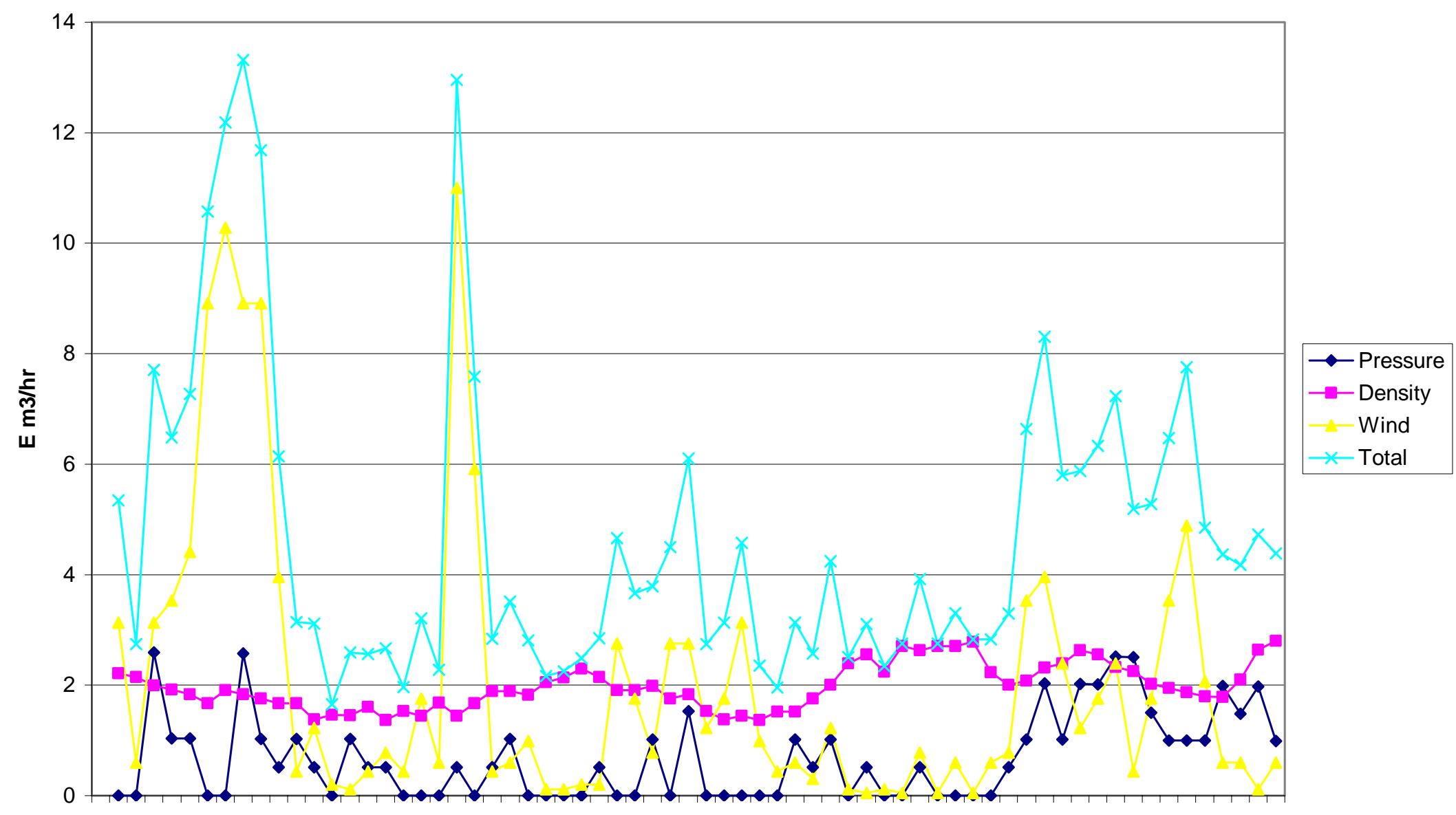

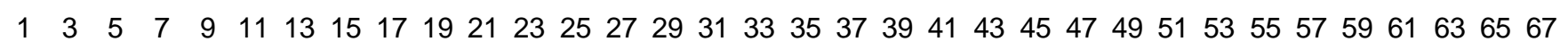
Elapsed data hours

Figure 9. Example of Projected Winter Hourly Tank Ventilation Rates 


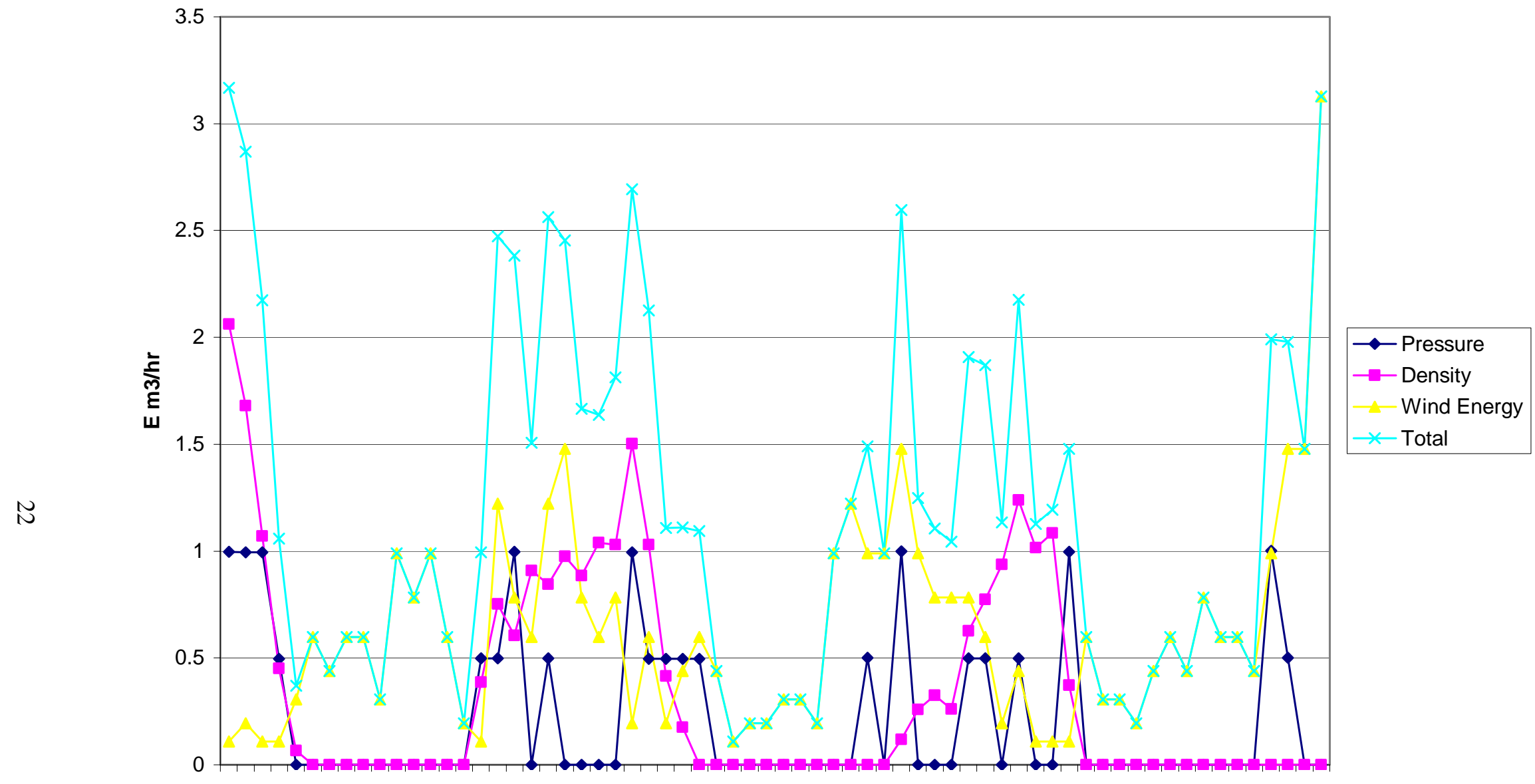

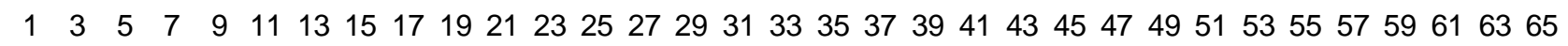

Elapsed data hours

Figure 10. Example of Projected Summer Hourly Tank Ventilation Rates 
be useful to the extent that the processes resulting in the complaints can be represented by hourly ventilation rates. The results will allow tests to be designed that can better address the complaints. The question of the importance of shorter term releases has not been resolved.

These observations guide parallel efforts by CH2M HILL to investigate historical tank vapor complaints.

\section{References}

Burk K. 2004. Personal communication about Hanford Meteorological Station microbarograph records for the Calendar Year 2003.

Huckaby JL, KB Olsen, DS Sklarew, JC Evans, and KM Remund. 1997. Measurements of Waste Tank Passive Ventilation Rates Using Trace Gases. PNNL-11683, Pacific Northwest National Laboratory, Richland, Washington.

Huckaby JL, JC Evans, DS Sklarew, and AV Mitroshkow. 1998. Waste Tank Ventilation Measured with a Tracer Gas Method. PNNL-11925, Pacific Northwest National Laboratory, Richland, Washington.

Huckaby JL, LM Peurrung, and PA Gauglitz. 1999. Gas Release During Saltwell Pumping:

Interpretation of Operations Data. PNNL-13029, Pacific Northwest National Laboratory, Richland, Washington.

Stock LM and JL Huckaby. 2000. A Survey of Vapors in the Headspaces of Single-Shell Waste Tanks. PNNL-13366, Pacific Northwest National Laboratory, Richland, Washington. 